ALICJA SENEJKO

Instytut Psychologii, Uniwersytet Wrocławski Institute of Psychology, Wroclaw University e-mail: alicja.senejko@uwr.edu.pl

DOMINIKA WIELAND-LENCZOWSKA

Instytut Psychologii, Uniwersytet Wrocławski Institute of Psychology, Wroclaw University

KRYSTYNA SZAŁKIEWICZ-BARGIEŁ

Prywatny gabinet psychologiczny, Wrocław Private therapeutic practice, Wroclaw

\title{
Research on Psychological Defense in a Context of Development after Trauma as Exemplified by Reactions of Young Women to Death of Their Child
}

\begin{abstract}
The basic aim of our theoretical and research activity is to prepare a research procedure and a theoretical basis for such procedure directed at diagnosing three possible ways of responding to trauma (absence of adaptation, adaptation and post-traumatic development) among people who were mentally stable before experiencing trauma. In subject literature, traumatic responses are most often described by grouping into three categories: absence of adaptation, adaptation, and post-traumatic growth (development). In our case study, we introduce two examined women, who had in common the type of traumas experienced. They are women between 29 and 32 years old (young adults) whose child had died in the last 3 to 5 years. We have therefore focused not on the description of individual steps in carrying out a single case diagnosing reaction to trauma, but on the presentation of preparing procedure for such a study, i.e. the description of consecutive steps that led us from the first question: what model will we use for the analysis of response to trauma and why this model and not the other one? to the last question: what set of methods will we use to investigate the response to trauma and why this one as opposed to some other? In this case study, we present ensuing answers to the questions raised together with their rationale, dilemmas and doubts accompanying their formulation.
\end{abstract}

Keywords: post-traumatic growth, psychological defenses, adaptation to trauma

\section{INTRODUCTION: DISCUSSION OF DEVELOPMENTAL ISSUES AFTER TRAUMA}

Although for most of us the traumatic event is associated with misfortune, it does not have to be linked only with losses, with worse function- ing. Moreover, lately, it has been increasingly emphasized that trauma can change the paths of human life for the better. Even though this is not a common position, and there has been a discussion over the last several years between writers who doubt the possibility of traumatic development and those who believe trauma can 
be a great life opportunity. In our case study, we present arguments of both parties, since we have also joined this scientific discussion through the Function-Action Model of Psychological Defense (F-AMPD) by Alicja Senejko $(2005,2010)$. So, one of the main aims of this article is to show differences between adaptive and developing ways to respond to trauma by describing two cases of subjects experiencing a similar trauma but reacting differently. We also want to show a universal model, F-AMPD in our opinion, by means of which we would like to characterize the factors underlying the non-adaptive, adaptive and pro-developmental response to trauma.

\section{EXEMPLARY MODELS DESCRIBING DEVELOPMENT AFTER TRAUMA AND ADAPTATION}

In our view, the discussion focused on the possibility/or lack of development after trauma, may be due to differences in understanding of the category "development" itself. In order to indicate them, theoretical models showing the place of the traumatic event and the manner of reacting to them within the system of human life activity are needed. Meanwhile, models presented in the area of traumatic research are based, first of all, on the summary of observed changes in behavior of traumatized patients and their inclusion into adaptive or developmental ones, depending on the recognition of investigators. This sometimes results in inclusion of the same factor by some to adaptive changes, and by others to developmental.

Subsequently, the representative of possibility of development after trauma, Ronnie Janoff-Bulman (1992), claimed that most victims of traumatic events, through cognitive reappraisals, and support from the loved ones (genuine support), can rebuild their inner world after the trauma, and are transformed from victims to survivors. The author has distinguished three post-traumatic growth indicators as new dispositions acquired after trauma:

1. strength through suffering, manifested in greater self-reliance, fortitude, selfrespect;
2. psychological preparedness, concerning changes in assumptive world, mainly from more optimistic to realistic;

3 . existential reevaluation, i.e. the appreciation of life as such and relationships with the loved/closest ones (Janoff-Bulman, 2004).

Similar positive changes after traumatic experience are also described in their model of posttraumatic growth by Richard Tedeschi and Lawrence Calhoun (1995). The above characteristics of growth after trauma are supplemented by: new opportunities in life adequate to one's own resources and surroundings (Tedeschi and Calhoun, 1996). The authors emphasize that struggle with trauma is the most important factor in the posttraumatic growth. As trauma they list: death of a loved one, divorce, birth of a sick child, loss of a home in a fire, or one's own illness. These categories are broader than those included in DSM V (2013), which primarily pertain to the life-threatening situation, sexual violence or exposure to aversive details of a traumatic event.

However, other authors include the mentioned above characteristics of the post-traumatic activity not in developmental but only in adaptive ones, facilitating return to the psychological balance from before the trauma. The widow's therapist and the author of the article on hardiness, George Bonanno (2004), argues, for example, that resilient people in a traumatic situation are able to cope through a number of difficulties in these circumstances. These are: self-enhancement, which secures well-being; repressive coping, which allows for avoiding unpleasant thoughts, emotions and memories; being joyous - helpful in reducing distress (Bonanno, Noll, Putnam, O’Neil, Trickett, 2003). These dimensions of resilience enable people to avoid Post Traumatic Stress Disorders (PTSD) and the suffering associated with them. However, according to Bonanno, effective reactions to trauma are included into a process of adaptation rather than growth (development), because in addition to the above-mentioned characteristics, resistant people have poor discernment of their own dispositions, limited social competences, and narcissistic qualities that arouse aversion in surrounding them people. 
Equally skeptical about the development after trauma is Steven Hobfoll with co-workers, Daphna Canetti-Nisim and Robert Johnson (2006). These authors claim, for example, that the so-called ,working over trauma” (understanding its meaning) and social support from the loved ones can only help rebuild disturbed sense of security, which is an example of adaptation rather than development. Their position confirms the results of research into the Israelis who survived trauma in the form of a terrorist attack. It emerges from these, that between the characteristics treated as a manifestation of development by the followers of post-traumatic growth, such as: more bonding in intimate relationships, appreciation of every-day reality, etc. - there are positive correlations with such questionable ethically and, therefore, developmentally, characteristics such as authoritarianism, readiness for ethnic exclusion, or consent to support political violence.

From this brief analysis, it is clear that if we confine ourselves to describing behavior after traumatic experience without locating it in the context of motivation and whole life activity of an individual, it will be difficult to prove why a particular behavioral profiles are among examples of adaptation, not of development, and vice versa. An example of this is a review of prisoners of war after World War II made by Maria Orwid, et al. (1964) or by Edyta Dębińska, and Krzysztof Rutkowski, who drew attention to various forms of survival in the face of trauma (Dębińska, Rutkowski, 2015).

\section{DEVELOPMENTAL OPPORTUNITIES AFTER TRAUMA FROM THE PERSPECTIVE OF FUNCTION- ACTION APPROACH TO PSYCHOLOGICAL DEFENSE}

By using the function-action model of psychological defense of an individual (F-AMPD) Senejko $(2005,2010)$, we consistently assume that human development consists in implementing the most important regulatory standards at a given stage of life and that the direction of human development is determined by them.
The most important individual's standards of regulation are essential motivational factors (needs, motives, values, beliefs, etc.), directing and affirming life and giving meaning to it. What if the activated standard of regulation will not be realized? If, for example, important for us sense of security will be upset in its realization by our serious illness? It is assumed in F-AMPD that such a condition is an objective threat to human development and will be perceived by the subject as a threat as well. The threat in subjective perception will be a feeling that we have trouble realizing something that is important to us. This is usually accompanied by strong fear, anxiety.

\section{CHARACTERISTICS OF PSYCHOLOGICAL DEFENSE FROM THE F-AMPD PERSPECTIVE}

The feeling of threat triggers a set of actions called defensive because of the function they perform in a particular threatening situation (Senejko, 2008). Psychological defense is activated to eliminate the resulting disruption of critical factors in our lives - and therefore of great importance for the course of human development. Senejko distinguishes two defense groups: psychic (mental) defenses (defensive actions) and psychosocial defenses, depending on whether there is a need to enter into social relations for the realization of defensive function. The second criterion for the division of defense activities is the contribution of their results to development. Distinguished are two groups of defenses: constructive and nonconstructive defenses.

The indicator of contribution of psychological defense in development is the developmental dimension of defense activity. It consists of the constructive type of psychological defense (i.e. the ratio of constructive defenses of the subject to nonconstructive ones with predominance of constructive ones) and diversity (abundance or scarcity) expressed in the number of defenses used. The greatest contribution of psychological defense to developmental processes is evidenced by the strong developmental dimension 
of psychological defense, which consists of large diversity (abundance) of defense activities and constructive type of psychological defense. The slightly weaker contribution of psychological defense to development defines the weak developmental dimension of defense activity, consisting of constructive type of psychological defense and low diversity (scarcity) of defense activities. Similarly, strong non-developmental dimension of defense activity consists of low diversity (scarcity) of defense activities and nonconstructive type of psychological defense (predominance of nonconstructive defenses over constructive). The weak non-developmental dimension of defensive activity consists in turn of nonconstructive type of psychological defense and a large variety (abundance) of defense activities.

\section{TWO STAGES OF REACTION TO TRAUMA}

The traumatic situation (trauma) involves a feeling that, from among the matters that are important to us, threatened is the realization of these definitely essential, the base of our existence, without which life loses its meaning and/or our sense of worth decreases. In the function-action model, trauma is treated as a strong threat that seriously disrupts the realization of the crucial ones - regulatory standards.

Psychological defense, understood as behavior manifested in a situation of trauma, is the result of activation of regulatory processes aimed at realizing two basic objectives: adaptive and developmental. By entering into a discussion on whether traumatic development is possible, Senejko assumes that it is possible but after the adaptation stage. She therefore reconciles two antagonistic sides to the dispute.

Consequently to F-AMPD model, the main indicators of adaptation to traumatic event will be, rather weak than strong, non-developmental dimension of psychological defense and absence of PTSD. This is because, as we assume, the purpose of adaptation is to minimize the negative effects of disturbances in realization of the most important regulatory standards. The defensive activities that are initiated at the ad- aptation stage are mainly directed, we assume with Senejko, at regulation (reduction) of strong negative emotions that interfere with the processing of traumatic information. As a result, transpires the subject's emotional preparation for an attempt to become aware of the importance of a traumatic event for a future life. The second group of defensive activities at the adaptation stage pertains to information processing processes, as a result of which we rework, incorporate traumatic information into existing schemes, i.e. assimilation; coming to terms with the state of things and the relative mental and emotional balance.

The purpose of post-traumatic development is, however, the struggle for activation of the standard threatened in its realization, or the emergence and realization of a new one (new ones). As Senejko assumes, the main indicators of post-traumatic development will be the developmental dimension of psychological defense (weak or strong) and absence of PTSD. The development after trauma in our approach is connected with determining (working out?) an overarching standard of regulation of the nature of life orientation, which marks the posttraumatic changes in the subject's view of the world and himself in the world. Potentially, according to us, we would see the new sense of life (but also of trauma!), touch the philosophical sphere, which in itself regulates both emotional and behavioral responses to the world and the role of the individual in this world.

The realization of the goal of post-traumatic development can take place through:

1. change to the existing ways of realizing the most important standards of regulation and objects associated with them, without changing the standards themselves (e.g. for the abused child the need for safety is still the most important, but it does not associate securing it with the alcoholic father and not through the "conspiracy of silence");

2. change at the level of the most important regulatory standards, resulting from regrouping of the existing ones (by giving them a new meaning) or by working out new ones; from integration with 
them of views about the world and I (e.g. a sprinter losing a leg in an accident starts studying sports journalism and thus realizes a need abandoned in the past).

The result of these defensive activities is accommodation and enrichment of existing cognitive structures with new dimensions at the level of regulatory standards and ways of their realization. They make it possible to treat trauma as a positive turning point in life (Senejko, 2008).

From the perspective of F-AMPD, lack of adaptation in the face of trauma expresses a strong non-developmental dimension of psychological defense and the presence of PTSD. Such an arrangement, we suppose, fixates an individual on experienced trauma, precluding both adaptive and especially developmental forms of defensive activity.

\section{TWO CASE STUDIES}

The presented model is currently being verified by us in a series of case studies. We are interested in whether derived from the model assumptions, pertaining to the characteristics of people for whom adaptation or development after trauma is accessible - find its confirmation in the real cases of persons included in our research. The method most fitting to our problem is in our approach a mixed method, qualitative-quantitative, case study based on in-depth interview (questionnaire) as well as on questionnaire measurements (Wortman, Silver, 1989). The case study explanation process can be understood as a process of interpreting specific variables from the perspective of an adopted approach (Maddi, 2008; Collins, 2014). In our case study this approach is F-AMPD. Depending on the purpose, the data used for case analysis is often a survey record, compared with the results of questionnaires and other methods.

\section{METHODS USED FOR CASE STUDIES}

To investigate the contribution of psychological defense to developmental processes, Senejko has developed a PSPDQ1-R questionnaire (Psy- chosocial and Psychic Defenses Questionnaire). The questionnaire examines the categories of threats (arising from family, school or professional problems, intimate, social, existential, social incidents, material problems, catastrophes, illness and death), categories of attitude towards threats (attitude and evaluation) and categories of defense: constructive Psychological, psychosocial), nonconstructive (psychic, psychosocial) (Senejko, 2010). The current version of questionnaire, PSPDQ1-R, contains 62 items. The participant responds on a four-step scale: Yes; Rather Yes; Probably Not; Not.

Sample items pertaining to the threats category: 4. participation in social riots, strikes, etc., or a real threat by them (social incidents); 5. lack of meaning in life, fear of the new tasks of life, or other fears felt in various social situations (e.g. shyness) (existential problems); 7. a serious threat to your own life or your loved ones, or the death of a loved one or the threat of death (illnesses and death); 17. terrorist acts, war, experiencing of disaster (flood, fire, etc.) or a real threat by these (catastrophes and disasters); 11. divorce, separation, addiction, cheating, or other serious family problems (family problems).

Sample items concerning the category of defenses: 35 . I tried not to think about the threat, move away from myself the thoughts about it (nonconstructive, psychic); 20. I intensely wanted to cope with the threat, I was disciplined and committed to the situation (constructive, mental); 18. I attended tutoring, therapy, courses, etc., in order to cope with the threat (constructive, psychosocial); 3. I threw myself into activities or entertainment, to be consumed enough by such activities in order to forget about the threat (nonconstructive, psychosocial). Results are calculated by assigning 1 point for checking "Yes" or "Rather Yes", 0 points for "Rather No" and "No". We add up - according to the key contained in the protocol PSPDQ1-R - points received for items comprising categories of threats and defenses.

Reliability of new version PSPDQ1-R is satisfactory, Cronbach's Alpha measures from 0,70 to 0,83 .

The second method is a DAR Survey prepared by Dominika Wieland-Lenczowska, Krystyna Szałkiewicz Bargieł and Alicja Senejko. 
The DAR Survey contains 60 questions concerning the past, present and anticipated future of the participant described at the context of trauma. In addition to closed questions and selection questions, it includes a place for respondent's independent testimony in openended questions.

The third method used was the revised version of IES (Impact of Event Scale), by Weiss and Marmar (1996), Polish translation by Zygfryd Juczyński and Nina Ogińska-Bulik (2010) which diagnoses PTSD (Post Traumatic Stress Disorder). The method consists of 22 statements describing symptoms of stress experienced in the last 7 days due to experienced traumatic event. The evaluation is based on a 5-point Likert scale $(0-4)$. It is used to determine the current subjective feeling of discomfort associated with a specific event. It encompasses three dimensions of PTSD: 1. Intrusion, expressing recurring images, dreams, thoughts or perceptual impressions associated with trauma; 2. Agitation, tension characterized by increased vigilance, fear, impatience, difficulty concentrating, and 3. Avoidance, manifested by efforts to get rid of thoughts, emotions or conversations associated with trauma. Numerical results obtained from adding up each scale: intrusion - these are answers to 8 questions, agitation - answers to 7 questions, and avoidance - answers to 7 questions. In evaluation of the IES-R score the assumption of a border value should take place, from which the person's results can be considered indicative of PTSD. In different studies, the limit value ranges from 1.4 to 1.5 (if we calculate the mean score) or 30-33 points (when calculating the sum for the whole scale). Below this value we diagnose the absence of PTSD, above we talk of presence of PTSD (Ogińska-Bulik, Juczyński, 2010).

The fourth method is PGI (The Post-Traumatic Growth Inventory) by Tedeschi and Calhoun (1996) in adaptation of Ogińska-Bulik and Juczyński (2010). It consists of 21 statements describing various changes that have occurred as a result of experienced traumatic event. In the original version, the inventory creates five scales, in the Polish revised version four scales: 1. Changes in self-perception (as a result of ex- perienced trauma an individual sees new possibilities and feels increased sense of personal strength) 2. Changes in relationships with others (increased sense of connection to others, increased empathy and altruism), 3. Greater appreciation of life (change of life philosophy, previous priorities, greater appreciation of each day) and 4. Spiritual changes (better understanding of spiritual problems and increase of religiosity). Raw results from individual scales are converted into stens. Results in sten score within range 1-4 are defined as low - no evidence of growth, 5-6 sten are considered average and 7-10 high, confirming individual's growth.

\section{THE PERSONS EXAMINED}

\section{Case study method}

In our work we introduce 2 out of 7 examined women who had in common the type of traumas experienced. They are women between 25 and 35 years old (young adults) whose child had died in the last 3 to 5 years. What is important, we have chosen such individuals who have had enough time since the event to anticipate the end of mourning - natural physical and psychological reactions to loss (Kübler-Ross, Kessler, 2007). For the protection of their personal data, we will use false names and will not disclose the details that may reveal the person under examination.

Person 1 - Anna. She is 32 years old (information from the DAR Survey). She comes from a full family, is an only child; her parents influenced her life, although the relationship between them was mainly task-oriented; she has changed now her family's evaluation to a more positive one. Material status met the family's needs. Puberty was for her the period of rebellion manifested beyond the established limits. She did not have or has difficulties in establishing social contacts, both with her peers and elderly people. She was a good student at school. She graduated economics. Immediately after her economic studies she started working and is still working; she is very satisfied with her professional position. She married 7 years ago. The 
event which she described as traumatic in the category of illness and death, the loss of one of the children - is not the only event that affects the life of the subject. When she was a child, her mother underwent cancer. According to the respondent, she was aware that it affects the whole family, she appreciated the importance of this event. Five years ago, Anna gave birth to twins. Initially her mother helped her, but after three months Anna had to deal with looking after the children herself. Asked about an event that changed her life: "[...] We were traveling together [...] I do not know how it happened that Kuba (one of my sons) swallowed this button, my coat in the car, I did not notice, the son began to choke. They did not have time to reach a hospital. The child died in the car, waiting for an ambulance". Anna lost her child 3 years ago. After experienced trauma, she is reacting more strongly to other difficult situations and is feeling helpless towards the other child. Anna became more vigilant and prudent. The respondent benefited from the support of relatives and institutions, believes that the support received at that time was sufficient for her. She does not use drugs or has thoughts of suicide. She assesses her health as having minor ailments, but generally good. Anna spends her free time meeting with family, playing with her son, working in the garden. The test results indicate satisfaction with current life, readiness to use the potential of the environment with low insight into one's own abilities.

DATA RECEIVED FROM OTHER METHODS: the subject obtained a result indicating a weak non-developmental dimension of psychological defense -6 nonconstructive psychic defenses and 2 constructive psychosocial ones. She also received a result indicating a very low indicators of symptoms from the post-traumatic stress disorder syndrome, mainly in the prevalence of avoiding stimuli associated with trauma and emotional arousal. Anna also obtained the low result of the symptoms of post-traumatic growth; the weakest transformation in the field of self-perception, the greatest in terms of spiritual changes. She responded affirmatively to $78 \%$ of questions about adaptation-related traumatic changes.

Diagnosis: adaptation after trauma.
Person 2 - Inga. She is 29 years old. She came from a dysfunctional family (her father left the family when she was 1.5 years old; stepfather had a problem with drinking control, there was violence), eventually she was raised by stepfather's grandparents in Germany. She has a brother, 7 years older than her; she has evaluated the relationship with her brother as free since childhood, "everyone had their own world". Currently Inga realizes that her father's absence affected her and the whole family - but when she was a child she did not realize it. She has been suffering from the "fish scales" disease since childhood; she is under constant dermatologist control. She denies taking any alcohol or psychoactive substances, as well as suicide attempts. At the period of adolescence, she decided to find a biological father, but he was murdered six months earlier. She also persuaded her mother to leave the stepfather and after this fact her relationship with her mother improved. Inga does not see a person who would have a positive impact on her life; her stepfather had negative influence. She describes her social relations as satisfying; she was in good relationships with selected people, with the rest- in average. She worked and till now she is working; she started working during her studies. At the age of 24, she became pregnant. The father of the child, when he learned that Ms. Inga was pregnant, broke up with her: "I was not particularly surprised by the child's father reaction - he was not ready to be a father." But she wanted to give birth and raise a child. She received support from that man's parents and from her own mother. Her son was born on time, without complications. When he was four months old, he suddenly died - due to infantile death - of Sudden Infant Death Syndrome (SIDS). The death of the child occurred 3.5 years ago. It was the most difficult trauma for her. Inga had to cope with the reaction of her social environment, people who look at her as a kind of mother, the sense of responsibility she felt in connection with the death of a child. The experienced situation related to trauma was an incentive to introduce important changes in her life, which she rates as positive. She verified the relationship with people who were important for her. Just now she has not such ruthless 
pursuit to control everything, Inga knows that she does not affect everything. She received the support from specialists; believes that the support received at that time was sufficient for her. She does not use drugs, alcohol or thinks of suicide. She estimates her health as stable, generally good. Inga spends her free time on traveling and training. On the basis of Inga's answers to the questions of the DAR Survey, it can be thought to be aware of the situation in which she found herself. She also eagerly uses the help and support from her the environment. The results in the scales examining the satisfaction of the examined life fluctuate around the maximum score of 10 points at the present stage.

DATA RECEIVED FROM OTHER METHODS: the subject obtained a testimonial of a strong developmental dimension of psychological defense - showing 4 non-constructive psychological defenses, 8 constructive defenses, including 4 psychic and 4 psychosocial constructive defenses. She also received a result indicating a very low incidence of symptoms from the post-traumatic stress disorder syndrome, mainly in the predominance of emotional arousal. The high result of the symptoms of post-traumatic growth is accompanied by the weakest transformation in the field of greater appreciation of life, the greatest in terms of changes in relations with people and in the perception of self. She responded affirmatively to $56 \%$ of questions about post-traumatic developmental changes and $21 \%$ of questions about post-traumatic changes towards adaptation.

Diagnosis: post-traumatic development.

Table 1 summarizes the results used for the characteristics of both persons under examination.

Table 1. Summary of the participant's results obtained through the applied methods

\begin{tabular}{|c|c|c|c|}
\hline Methods & $\begin{array}{l}\text { Categories } \\
\text { /indicators } \\
\text { of description }\end{array}$ & $\begin{array}{l}\text { Diagnosed Anna } \\
32 \text { years old }\end{array}$ & $\begin{array}{l}\text { Diagnosed Inga } \\
29 \text { years old }\end{array}$ \\
\hline \multirow{4}{*}{$\begin{array}{l}\text { PSPDQ1-R } \\
\text { diagnosing type and } \\
\text { dimension of psychic } \\
\text { (mental) and psychoso- } \\
\text { cial defenses }\end{array}$} & defenses applied & $\begin{array}{l}6 \text { nonconstr. psychic, } \\
1 \text { constr. psychosocial }\end{array}$ & $\begin{array}{l}4 \text { nonconstr. psychic } \\
4 \text { constr. psychic } \\
4 \text { constr. psychosocial }\end{array}$ \\
\hline & $\begin{array}{l}\text { dimension of psycho- } \\
\text { logical defense }\end{array}$ & $\begin{array}{l}\text { non-developmental } \\
\text { dimension }(6 / 1)\end{array}$ & $\begin{array}{l}\text { developmental dimen- } \\
\text { sion }(8 / 4)\end{array}$ \\
\hline & number of defenses & 7 - abundance & 12 - abundance \\
\hline & $\begin{array}{l}\text { contribution of defense } \\
\text { in developmental pro- } \\
\text { cesses }\end{array}$ & $\begin{array}{l}\text { weak non-developmen- } \\
\text { tal dimension of } \\
\text { psychological defense }\end{array}$ & $\begin{array}{l}\text { strong developmental } \\
\text { dimension of psycho- } \\
\text { logical defense }\end{array}$ \\
\hline \multirow{4}{*}{$\begin{array}{l}\text { IES-R } \\
\text { diagnosing PTSD }\end{array}$} & intrusion & 3 & 8 \\
\hline & emotional arousal & 7 & 10 \\
\hline & avoidance & 9 & 9 \\
\hline & total & 19 & 27 \\
\hline \multirow{5}{*}{$\begin{array}{l}\text { PTGI } \\
\text { diagnosing post-trau- } \\
\text { matic growth }\end{array}$} & $\begin{array}{l}\text { changes in self-percep- } \\
\text { tion }\end{array}$ & 15 & 39 \\
\hline & $\begin{array}{l}\text { changes in relationships } \\
\text { with others }\end{array}$ & 13 & 26 \\
\hline & $\begin{array}{l}\text { greater appreciation } \\
\text { of life }\end{array}$ & 6 & 10 \\
\hline & spiritual changes & 5 & 8 \\
\hline & total/ sten: & $39 / 3$ & $83 / 9$ \\
\hline
\end{tabular}




\begin{tabular}{|c|c|c|c|}
\hline Methods & $\begin{array}{c}\text { Categories } \\
\text { /indicators } \\
\text { of description }\end{array}$ & $\begin{array}{c}\text { Diagnosed Anna } \\
32 \text { years old }\end{array}$ & $\begin{array}{l}\text { Diagnosed Inga } \\
29 \text { years old }\end{array}$ \\
\hline \multirow{2}{*}{$\begin{array}{l}\text { DAR survey - } \\
\text { diagnosing adaptation } \\
\text { or development }\end{array}$} & confirming adaptation & 11 of 14 answers & 3 of 14 answers \\
\hline & confirming development & 0 of 16 answers & 9 of 16 answers \\
\hline $\begin{array}{l}\text { DAR survey - diagnos- } \\
\text { ing insight }\end{array}$ & insight & $\begin{array}{c}24 \text { - has weakened } \\
\text { insight }\end{array}$ & 4 - has insight \\
\hline $\begin{array}{l}\text { DAR survey - } \\
\text { diagnosing life satis- } \\
\text { faction }\end{array}$ & life satisfaction & $\begin{array}{c}\text { "for" }-7 \text { of } 10 \text { answers } \\
\text { "against" }-2 \text { of } 10 \\
\text { answers }\end{array}$ & $\begin{array}{c}\text { "for" }-8 \text { of } 10 \text { answers } \\
\text { "against" }-2 \text { of } 10 \\
\text { answers }\end{array}$ \\
\hline $\begin{array}{l}\text { DAR survey - } \\
\text { diagnosing support }\end{array}$ & support & 5 of 7 answers & 6 of 7 answers \\
\hline $\begin{array}{l}\text { overall assessment } \\
\text { (diagnosis) }\end{array}$ & & $\begin{array}{l}\text { post-traumatic } \\
\text { ADAPTATION }\end{array}$ & $\begin{array}{c}\text { post-traumatic } \\
\text { DEVELOPMENT }\end{array}$ \\
\hline
\end{tabular}

\section{DISCUSSION}

The present study in the form of an analysis of two cases was an illustration of our way of analyzing and investigating difficult issues related to the reactions after trauma in the context of development processes trying to integrate existing knowledge about trauma. Authors of studies on the reaction to trauma stress that adaptation is possible mainly due to the so-called coping processes involved in dealing with difficult situations (Haan, 1977; Vaillant, Vaillant 1993; Cramer, 2006). They are purposefully targeted by the individual and are an attempt to cope with the new reality (Lazarus, 1999; Cramer, 2006). Many authors of the concept of adaptation after trauma (Hobfoll, 1989; Grzegołowska-Klarkowska, Żołnierczyk, 1990; Hentschel et al., 2004; Bonnano, Diminich, 2013), also emphasized the adaptive role of defense mechanisms, consisting mainly in reducing anxiety and regulating other negative emotions after experienced trauma.

Our approach, based on the F-AMPD model, assumes the co-presence of both conscious and intentional, as well as unconscious and unintentional mechanisms involved in the trauma response system, in the form of a developmental or non-developmental dimension of psychological defense. According to some authors (Tedeschi, Calhoun, 1996; 2004; Janoff-Bulman, 2004), studies of post-traumatic development are concentrated mainly on human activities aimed at fighting the effects of trauma in its broad sense and on acquiring and developing new, constructive skills and traits. Among the new properties desirable from the point of view of the individual, they pay attention to: strength through suffering, fortitude, psychological preparation, changes in assumptions about the world and its functioning; existential reevaluation through the appreciation of life as such and relationships with loved ones, and perceiving new opportunities in life adequately to own resources and surroundings.

The examples of behavior of the respondents described in our article show that the same trauma can be responded to both in the form of reactions supporting the development processes as well as the damaging ones.

The present study is the illustration of our broader research connecting to the factors that determine the response after trauma in the dimensions of non-adaptation, adaptation and development after trauma.

As is evident from schematically presented characteristics of two case studies, both subjects have a similar level of life satisfaction and have probably received sufficient levels of social support to cope with traumatic experiences. This is manifested in both of them by absence of manifestations of PTSD. However, in the profiles of 
post-traumatic behavior, these women are significantly different. Ms. Inga has predominance of constructive defenses over nonconstructive ones, which indicates the developmental dimension of psychological defense. Let's recall that according to our model of development after trauma, this is a basic development indicator after trauma. This subject is also characterized by a high level of post-traumatic growth, especially in the areas of change in self-perception and change in relationships with others. In the study, she reveals a high level of insight into her life situation. Perhaps a relatively high Intrusion Score (IES-R) is associated with an intense transformation of the self and the world after trauma (Tedeschi, Calhoun, Cann, Solomon, 2010) - but it requires further research. The respondents' answers to the survey on social relationships indicate positive impact of these relationships (with peers as well as adults) on building social competencies, mental resilience, and overall life satisfaction (Sanders, 2001).

Contrary to Ms. Inga, Mrs. Anna displays predominance of nonconstructive defenses (definitely psychic), which is a proof of the non-developmental dimension of defense, or adaptive rather than developmental - the stage of reaction to trauma. This respondent is characterized by a low level of post-traumatic growth, especially in the areas of change in self-perception and change in relationships with others. Mrs. Anna, unlike Ms. Inga, reveals a low level of insight into her own life situation. This configuration of results indicates that, presumably, her traumatic responses are more likely to be based on her own, rather limited mental resources, while not sufficiently using social resources (Maddi, 2008). The subject's responses to social relationships survey confirm our assumptions and point to potential opportunities for her post-traumatic development in this area.

The above analysis allows us to formulate the following final conclusions:

The F-AMPD model can be used as a basis for analyzing an examined person's reactions to trauma. It allows to diagnose at what stage a person is (adaptive or developing) and extensively characterize defenses that he or she possesses in manifested traumatic reaction.

A case study in conjunction with questionnaires and surveys provides satisfactory amount of information. Therefore, the collected methods allow to diagnose a type of traumatic response: adaptation or development and to distinguish areas of significance, the improvement of which is linked/intertwined with possibility of further development of the subject.

The described cases illustrating the use of both the model and the PSPDQ-1R method integrally linked to the model demonstrate, in our view, that it is possible not only to reconcile positions pertaining to "adaptation or development after trauma". It is also possible, as we have shown, to formulate a conception that is a distinct contribution to the field of research and models related/pertaining to this subject. The presented research constitutes inducement to organize further research into determinants of lack of adaptation, adaptation and development after trauma, as well as to search for factors conditioning transition from adaptation stage to post-traumatic development.

\section{REFERENCES}

American Psychiatric Association (2013), Diagnostic and Statistical Manual of Mental Disorders (DSM-5), Fifth Edition. ISBN: 978-0-89042-555-8.

Beaton R.D., Murphy S., Johnson L.C., Nemuth M. (2004), Secondary traumatic stress response in fire fighters in the aftermath of 9/11/2001, Traumatology, 10(1).

Bensimon M. (2012), Elaboration on the association between trauma, PTSD and posttraumatic growth: The role of resilience. Personal and Individual Differences, 52(7), 782-787.

Bonanno, G. A. , Noll, J. G. , Putnam, F. W. , O’Neil, M. ,\& Trickett, P. K. (2003). Predicting the willingness to disclose childhood sexual abuse from measures of repressive coping and dissociative tendencies. Child Maltreatment, 8(4), 302-318. 
Bonanno G.A. (2004), Loss, trauma and human resilience: have we underestimated the human. capacity to thrive after extremely aversive events? American Psychologist, 59(1), 20-28.

Bonnano G.A., Diminich E.D. (2013), Annual research review: Positive adjustment to adversity - trajectories of minimal-impact resilience and emergent resilience. Journal of Child Psychology and Psychiatry, 54(4), 378-401.

Collins, R. E. (2014). Fear and Marginalization: A Mixed-Methodological Approach of the Language in Four Canadian Newspapers. In SAGE Research Methods Cases. 2014. [DOI http://dx.doi.org/10.4135/97814 4627305013514659]

Cramer P. (2006), Protecting the Self: Defense Mechanisms in Action. New York: Guilford Press.

Cramer V., Torgersen S., Kringlen E. (2006), Personality disorders and quality of life: a population study. Com. Psychiatry, 47, 178-184.

Dębińska E., Rutkowski K. (2015), Powojenne badania stresu pourazowego w Krakowie [Post-war examination of post-traumatic stress in Krakow]. Cz. II. Badania po 1989 roku. Psychiatria Polska, 21,1-15.

Epstein S. (1998), Temperament and personality theory: the perspective of cognitive-experiential self-theory. School Psychology Review, 27(4), 534-556.

Erdelyi M.H. (2001), Defense processes can be conscious or unconscious. American Psychologist, 56, 761-762.

Fenichel O. (1945), Nature and classification of the so-called psychosomatic phenomena. Psychoanalytic Quarterly, 14, 287-312.

Foa E.B., Rothbaum B.O., Furr J.M. (2003), Augmenting exposure therapy with other CBT procedures. Psychiatric Annals, 33, 47-53.

Freud A. (1963), The concept of development lines. The Psychoanalytic Study of the Child, 18, 245-265.

Freud S. (1966), The Standard Edition of the Complete Psychological Works of Sigmund Freud. London: Hogarth Press and The Institute of Psychoanalysis.

Grzegołowska-Klarkowska H., Żołnierczyk D. (1990), Predictors of defense mechanisms under conditions of threat to the objective self: Empirical testing of a theoretical model. Polish Psychological Bulletin, 21, 129-155.

Haan N. (1977), Coping and Defending: Processes of Self-environment Organization. New York: Academic Press.

Hentschel U., Smith G., Draguns J.G., Ehlers W. (eds.) (2004), Defense Mechanisms: Theoretical, Research and Clinical Perspectives (vol. 136). Amsterdam: Elsevier B.V.

Herman J.L. (1998), Recovery from psychological trauma. Psychiatry and Clinical Neurosciences, 52, 98-103. doi:10.1046/j.1440-1819.1998.0520s5S145.x

Hobfoll S.E. (1989), Conservation of resources: A new attempt at conceptualizing stress. American Psychologist, 44(3), 513-523.

Hobfoll, S. E., Canetti-Nisim, D., Johnson, R.J. (2006). Hobfoll, S. E., Canetti-Nisim, D., \& Johnson, R.J. (2006). Exposure to terrorism, stress-related mental health symptoms, and defensive coping among Jews and Arabs in Israel. Journal of Consulting and clinical psychology, 74(2), 207.

Janoff-Bulman R. (2004), Posttraumatic Growth: Three Explanatory Models. Psychological Inquiry, 15(1), 30-34.

Juczyński Z., Ogińska-Bulik N. (2009), Measurement of post-traumatic stress disorder - Polish version of Impact Event Scale-Revised, Psychiatria, Via Medica, t. 6, nr 1, 15-25.

Kolańczyk A. (1999), Czuję, myślę, jestem [I feel, I think, I am]. Gdańsk: Gdańskie Wydawnictwo Psychologiczne.

Kübler-Ross, E., Kessler, D. (2007). On Grief and Grieving: Finding the Meaning of Grief Through the Five Stages of Loss. New York: Scribner.

Lazarus R.S. (1999), Stress and Emotion. A New synthesis. New York: Springer Publishing Company.

Lis-Turlejska M. (1998), Traumatyczny stres. Koncepcje i badania [Traumatic stress: models and research]. Warszawa: Wydawnictwo Instytutu Psychologii PAN.

Maddi, S. R. (2008). The courage and strategies of hardiness as helpful in growing despite major, disruptive stresses. American Psychologist, 63, 563-564.

Ochberg M.F. (1995), Post-traumatic therapy. W: G.S. Everly, J.M. Lating (eds.), Psychotraumatology: Key Papers and Core Concepts in Post-traumatic Stress. New York: Plenum.

Oginska-Bulik N. (2005), Emotional intelligence in the workplace: Exploring its effects on occupational stress and health outcomes in human service workers. International Journal of Occupational Medicine and Environmental Health, 18(2), 167-175.

Ogińska-Bulik N., Juczyński Z. (2010), Rozwój potraumatyczny - charakterystyka i pomiar [Posttraumatic growth: characteristics and measurement]. Psychiatria, 7(4), 129-142. 
Orwid M., Szymusik A., Teutsch A. (1964), Cel i metoda badań psychiatrycznych byłych więźniów obozu koncentracyjnego w Oświęcimiu [Aim and method of psychiatric examinations of former prisoners of the concentration camp in Oświęcim]. Przegląd Lekarski, 1, 9-11.

Sanders C. (2001). Jak przeżyć stratę dziecka. Powrót nadziei. Gdańsk: GWP.

Senejko A. (1995), Aktywność obronna dzieci [Children defensive activity of]. Wrocław: Wydawnictwo Uniwersytetu Wrocławskiego.

Senejko A. (2005), Psychological defense in adolescents and adults. Polish Psychological Bulletin, 36(3), $163-174$.

Senejko A. (2008), Subjective determiners of treating the final secondary school examination as a threat. Polish Psychological Bulletin, 39(3), 118-128.

Senejko A. (2010), Obrona psychologiczna jako narzędzie rozwoju [Psychological defense as a developmental tool]. Warszawa: Wydawnictwo Naukowe PWN.

Tedeschi R.G., Calhoun L.G. (1995), Trauma \& Transformation: Growing in the Aftermath of Suffering. Thousand Oaks: Sage Publications.

Tedeschi R.G., Calhoun L.G. (1996), The Post-Traumatic Growth Inventory: Measuring the positive legacy of trauma. Journal of Traumatic Stress, 9, 455-471.

Tedeschi R.G., Calhoun L.G. (2004), Posttraumatic growth: Conceptual foundations and empirical evidence. Psychological Inquiry, 15(1), 1-18.

Tedeschi R.G., Calhoun L.G., Cann A., Solomon D.T. (2010), Posttraumatic growth and depreciation as independent experiences and predictors of well-being. Journal of Loss and Trauma, 15, 151-166.

Tolin D.F., Foa E.B. (2006), Sex differences in trauma and posttraumatic stress disorder: A quantitative review of 25 years of research. Psychological Bulletin, 132, 959-992. http://dx.doi.org/10.1037/0033-2909.132.6.959.

Weiss D.S., Marmar C.R. (1997), The impact of Event Scale-Revised. In: J.P. Wilson, T.M. Keane (eds.), Assessing Psychological Trauma and PTSD: A Practitioner's Handbook, 399-411. New York: Guilford Press.

Weiss D.S. (2004), The Impact of Event Scale-Revised. In: J.P. Wilson, T.M. Keane (eds.), Assessing Psychological Trauma and PTSD: A Practitioner's Handbook, 2nd ed., 168-189. New York: Guilford Press.

World Health Organization (1999), ICD-10 Classification of Mental and Behavioural Disorders, World Health Organization.

Wortman C.B., Silver R.C. (1989). The myths of coping with loss. Journal of Consulting and Clinical Psychology, 57(3), 349.

Wrosch C., Heckhausen J., Lachman M.E. (2000), Primary and secondary control strategies for managing health and financial stress across adulthood. Psychology and Aging, 15, 387-399.

Vaillant C.O., Vaillant G.E. (1993), Is the U-curve of marital satisfaction an illusion? A 40-year study of marriage. Journal of Marriage and the Family, 55(1), 230-239.

Van Der Kolk B.A. (1998), Trauma and memory. Psychiatry and Clinical Neurosciences, 52: S52-S64. doi:10.1046/j.1440-1819.1998.0520s5S97.x.

\section{Links to relevant miscellaneous web resources}

Collins R.E. (2014), Fear and Marginalization: A Mixed-Methodological

Approach of the Language in Four Canadian Newspapers. SAGE Research Methods Cases. 2014. [DOI http:// dx.doi.org/10.4135/978144627305013514659]

Mooney S. (2014), Qualitative Interviewing with Vulnerable Populations:

Ethical Considerations When Conducting Narrative Interviews with Young People with Cancer. SAGE Research Methods Cases. 2014. [DOI: http://dx.doi.org/10.4135/978144627305013509184]

Mauceri S. (2014), Teenage Homophobia: A Multilevel and Integrated

Survey Approach to the Social Construction of Prejudice in High School. SAGE Research Methods Cases. 2014. [DOI: http://dx.doi.org/10.4135/978144627305013503433]

Waldner L.K. (2015), Stigma Management Techniques of Gay Skinheads: A Content Analysis of a Gay Racist Website and Message Boards. SAGE Research Methods Cases. 2015. [DOI: http://dx.doi.org/10.4135 /978144627305014556855] 